\title{
Pharmacological Potentials of Royal Jelly in Dentistry: A Review
}

\author{
Review Article
}

Wayakar Rutuja ${ }^{*}$, Thosar Nilima², Rathi Nilesh³, Srivastava Rashi', Mehta Jayati1

1. PG Scholar, 2. Professor and Head of the Department, 3. Reader,

Department of Pediatric and Preventive Dentistry, Sharad Pawar Dental College,

Datta Meghe Institute of Medical Sciences, Wardha, Maharashtra, India.

\begin{abstract}
"Royal Jelly" is a viscous material which is secreted by the cephalic gland of the "worker bee." This is the key component of the "queen bee's" diet, rendering it with longer life span compared to worker bees."Royal Jelly" possess various pharmacological properties. These includes antioxidant, neurotropic, anti-inflammatory, immunomodulatory and antibiotic, anti-aging, antihypertensive properties. This article summarizes biological properties, composition, criteria of quality evaluation of "Royal Jelly"and published studies on the efficacy of "Royal Jelly" as a "wound healing agent", as a component of mouth wash used in treatment of oral mucositis, periodontal diseases, as a storage media and as a pulp capping agent."Royal Jelly" can emerge as a viable alternative to conventional synthetic agents, which may avoid usual drawbacks of synthetic medicaments.
\end{abstract}

Key Words: Royal Jelly, Honeybee, Oral health, Apicultural pulpotomy medicaments, Queen bee.

\section{Introduction}

"Royal Jelly" is a glandular secretion of the worker bees.(1) During initial days of maturation process all larvae use Royal Jelly as their food. However, for the queen bee, "Royal Jelly" is the food for their life.(2) This is the reason why queen bee has numerous benefits which includes its bigger size than all the other bees, and longer lifespan which ranges from 5-6 years, and that of working bee is only $35-40$ days. (3)(4)(5)

\section{Composition of Royal Jelly and its quality evaluation}

Chemically, "fresh Royal Jelly" comprises " 50 $70 \%$ water", "7-18\% carbohydrates", "9-18\%proteins", "3-8\% fat", " $1.5 \%$ minerals"(Ca.) and minor quantities of polyphenols and various vitamins. Its colour ranges from whitish to yellowish colour. (6)(7) The yellow shade deepens upon storage. It has pungent odour, tastes sour and sweet. Proper storage of "Royal Jelly" is necessary; otherwise it has a tendency to become darker and rancid. It has $\mathrm{pH}$ in the range of 3.4-4.5 and a density of $1.1 \mathrm{~g} / \mathrm{mL}$. (7) It is not completely soluble in water. To maintain best possible quality, it should be stored at freezing temperature. This will avert disintegration of bio-active proteins of "Royal Jelly". Therefore, it should be frozen as soon as it is extracted. (7)(8)

\section{* Corresponding Author:}

Wayakar Rutuja

PG Scholar, Department of Pediatric and Preventive

Dentistry, Sharad Pawar Dental college, Datta

Meghe Institute of Medical Sciences, Wardha,

Maharashtra. India.

Email Id: rutubwaykar@gmail.com

\section{Biological properties of Royal Jelly}

Bioactive components of "Royal Jelly" and its possible role in mechanism of action as per the previous studies conducted are presented below in a categorised manner that will allow a medical articulacy.

\section{Antimicrobial property}

As per the evidences of numerous studies, the principal antimicrobial property of "Royal Jelly" is accredited to its lipid component i.e. 10HDA. (9) (10) However, "Royal Jelly" possess proteins and peptides (11) (12) which shows antibiotic activity against different pathogens. (13) (14) (15) (16) It usually contains $7-8 \%$ of protein, out of which $80 \%-90 \%$ is "Major Royal Jelly Protein" (MRJPs).(17)(18) Amongst "MRJPs", "MRJP -2", and "MRJP -4"possess antimicrobial properties against bacteria, yeast. This is achieved by inducing cell wall and cell membrane impairment and dysfunction. (19)(20) "Royal Jelly" also contains peptides named Royalisin and lipid constituent which is 10-HDA both has antibacterial (Gram+, Gram-), antifungal properties (12) (16). Strong antibacterial activity of Royalisin is due to its 3 intramolecular disulfide bonds which are present between cysteine residues (22) Whereas other peptides such as "Jelleine I-III", “ Jelleine- II" , and " JelleineII" (phosphorylated) possess antimicrobial properties against yeast and against both Gram+, Gram- bacteria. (22) (11) Antimicrobial peptides are positively charged owing to presence of "Lysine", " Arginine", and "Histidine". These positively charged peptides interact with negatively charged phospholipids of the cell membrane and cause cell wall impairment. (23) According to Han et al. when threonine traces in Jelleines are phosphorylated they delivered a negative charge to "Royal Jelly" peptides. This resulted in 
significant reduction in antibiotic activity. Thus, the study concluded that the net charge of "Jelleines" possibly plays essential role in antibiotic property of "Royal Jelly". (22) (5)

\section{Wound-healing property}

It shows wound healing activity by reducing exudation along with formation of collagen in granulation tissue, whereas another mechanism is by reducing the capillary permeability, thereby decreasing healing period of desquamated skin lesion.(24)Other possible mechanism is by reducing the formation of "TNF $\alpha$, IL 1, IL6", reactive oxygen species (ROS) and increasing production of collagen I and collagen III.(25) Constituents of royal jelly and its possible role in wound healings are as follows: 10HDA encouraged the production of TGF- $\beta 1$, which is essential for collagen production.(26) A chief protein component, MRJ- 2, 3, 7 stimulates growth as well as migration of keratinocytes. (27) Royal Jelly's defensin-1 peptides improve matrix metalloproteinase- 9 secretion and movement of keratinocytes there by repairing the wound in a brief period of time. (28) Moreover other peptides like royalisin provides antimicrobial wound protection. Thus, these components can initiate the development of new wound healing medication.

\section{Antioxidant activity}

To get best antioxidant activity "Royal Jelly" should be extracted subsequently after 24 hours of the larval transfer. As per literature, "Royal Jelly" shows its antioxidant effect by increasing "catalase" (CAT) activity, along with reduction of "malondialdehyde" (MDA) levels which is indicator of oxidative stress.(29)

\section{Studies of Royal Jelly related to dentistry}

\section{Efficacy of "Royal Jelly" on Periodontal diseases}

The clinically important periodontopathic bacteria present at sites of disease activity are "Porphyromonas gingivalis (Pg)", "Aggregatibacter actinomycetemcomitans (Aa)", "Fusobacterium nucleatum (Fn)", "Prevotella intermedia (Pi)", "Tannerella forsythia", and"Parvimonas micra". (30) (31) New approaches for treatment of periodontal disease have been developed and especially the discovery of alternative treatments that will partially or totally exclude the use of antibiotics. Antimicrobial action of RJ has already been shown, and various studies report on antibacterial and antifungal actions.

- According to the study conducted by Coutinho D, Karibasappa SN, Mehta DS. 2018, the minimum bactericidal concentration values of Royal Jelly are in the range between 12.5 and $100 \mu \mathrm{g} / \mathrm{ml}$. "Royal Jelly" possess active antimicrobial agents such as royalisin and $10 \mathrm{HDA}$, which are absent in other bee products. According to study results the inhibitory effects on "Porphyromonas gingivalis" $(\mathrm{Pg})$ and "Prevotella Intermedia" (Pi) at lower concentration. However, higher concentrations were required to inhibit the growth of "Aggregatibacter actinomycetemcomitans" and "Fusobacterium nucleatum" (Fn) (12.5 to $100 \mathrm{ug} / \mathrm{ml})$. (15)

- "Periodontal diseases" are mostly accompanied by bone resorption. "Porphyromonas Gingivalis" is the commonest pathogenic bacteria of chronic inflammation in periodontium. In response to lipopolysaccharides of "Porphyromonas Gingivalis", PDLcells produce inflammatory cytokines and chemokines. Also, CD54 is the surface adhesion molecule whose levels are increased at inflammatory sites in periodontal lesions. According to the animal study carried out by Yanagita $M$ et al, Royal Jelly reduced "Porphyromonas Gingivalis" cell wall induced interleukin- 6 as well as CXC chemokine ligand 10 formations from MPDL22 cells. Also, Royal Jelly reduced the production of adhesion molecule i.e. CD54 from MPDL22 cells which usually increases in diseased condition.(32) These findings suggest that Royal Jelly has osteoinductive and anti-inflammatory effect and the study concluded that it can provide aids in the treatment and prevention of periodontal diseases.

\section{Bone healing}

Researchers have suggested possible role of "Royal Jelly" in bone healing, which is by inducing collagen cross linking gene expression and regulating formation of enzymes of collagen-modifying in vitro. Thus, by controlling the post translational alterations of type "I collagen", "Royal Jelly" can enhance bone quality. (33) In vivo human study should be carried out further to evaluate scope of "Royal Jelly" in Periodontal Diseases.

\section{Royal jelly as storage media}

Many studies have revealed the importance of the viability of "PDL cells" at the root surface as a crucial factor for durable success of the replanted teeth after avulsion, since they are needed for new PDL tissue regeneration. However, Royal Jelly has positive effect on wound healing process by way of encouraging human dermal fibroblast migration whereas there is increase in collagen production of skin fibroblast by the function of $10 \mathrm{H} 2 \mathrm{DA}$ by encouraging production of “TGF- $\beta 1 " .(34)(35)$

- Study conducted by Yanagita et al. has revealed that "Royal Jelly" at the concentrations between $4-500$ $\mu \mathrm{g} / \mathrm{ml}$ were not toxic to PDL cells. In another study which was conducted by, Dhanesuan et al validated that "Royal Jelly" crude extract at the concentrations from $0.1-1 \mathrm{mg} / \mathrm{ml}$ enhanced PDL cell proliferation while significant inhibition was observed with "Royal Jelly" at5mg/ml. (36)

- However, study was carried out Sricholpech M, Srisupabh D 2015, to evaluate the efficacy of "Royal Jelly" regarding viability and function of "periodontal ligament fibroblasts" (PDLF) in an in vitro tooth avulsion model. According to the study results Royal Jelly solutions dose dependently 
maintain higher PDLF (periodontal ligament fibroblasts) viability compared to HBSS $(p<0.05)$. However, results were comparable with that of low fat milk, when "Royal Jelly" solution was used as transport media at 500 and $900 \mu \mathrm{g} / \mathrm{ml}$ concentrations. Also, "Royal jelly" solutions promoted proliferation of the survived PDLF when compared to HBSS. These findings demonstrate potential of "Royal Jelly" as a Transport media.(37)

\section{Effect of Royal Jelly Oral mucositis}

Currently, as there is no definitive preventive measure for radiation induced oral mucositis, the therapy which gives symptomatic relief is essential. Considering the pharmacological potentials of "Royal Jelly", its effects on oral mucositis can be beneficial, so various studies conducted regarding it are mentioned below: As per the study conducted by Erdem Ö, Güngörmüs Z. 2016, when "Royal Jelly extract" is swished for 30 secs orally, 2 times /day, of total dose of $1 \mathrm{~g} /$ day showed marked reduction in the signs, symptoms and healing time of oral mucositis.(38) However, according to the study carried out by Watanabe S et al, use of "Royal Jelly films" in the early stages of "oral mucositis" was more beneficial than late stages.(39)

\section{Effect of Royal Jelly application on wounds}

Fewer experiments have tested the application of "Royal Jelly" on wound healing, as seen below:

\section{Diabetic foot ulcer}

Abdelatif et al, used "Pedyphar ointment" (Royal Jelly and panthenol in an ointment base) for dressing of "diabetic foot ulcer". "Pedyphar ointment" which contains "Royal Jelly", promoted healing by creating an alkaline environment in the wound, while the antimicrobial, immunomodulating and nutritional properties of "Royal Jelly" and "panthenol" help eradicate infection and promote healing. Study concluded that "Pedyphar ointment" can be a promising and safe conservative local treatment. (40)

\section{Role in granulation tissue formation}

Whereas the study conducted by Fujii et al. presented some anti-inflammatory activity by decreasing exudation and collagen formation in granulation tissue with Royal Jelly. It also shortened the healing period of desquamated skin lesions. (24)

\section{Use of Royal Jelly in candidial infection}

Denture sore mouth involves $60 \%$ of the population of denture wearer. C. albicans is the most common causative microorganism which tend to cause denture stomatitis. (41) The antifungal medications are can lead to drug-resistance when used continuously. Recently, consecutive studies regarding antibacterial activity of "Royal Jelly", a natural product, have been published.(42) (16) Studies regarding it are in the literature as follows: -
- Study was carried out by Danai Jet al 2017, where he placed the samples of heat-cured, self-cured acrylic resin as well as tissue conditioners in a various concentration of "Royal Jelly" extract solution, keeping Nystatin as the comparator group. Royal Jelly inhibited the adherence of C. albicans between $25-50 \mathrm{mg} / \mathrm{mL}$ concentration which was equivalent to $23 \mathrm{mg} / \mathrm{mL}$ Nystatin. Hence, "Royal Jelly" might even be Nystatin's substitute as an anti-fungal product. (43)

- Moselhy et al. carried out similar study where significant antifungal efficacy of "Royal Jelly" against "C. albicans" "Aspergillus fumigant", "Syncephalastrum racemosum", "Aspergillus niger" was found. The most appropriate concentration observed was $15 \mathrm{mg} / \mathrm{mL}$. However, larger zone of inhibitions were resulted at higher concentrations. (43)

\section{"Royal Jelly" as Pulpotomy medicament}

Numerous studies have reported healthpromoting activities of "Royal Jelly" such as antimicrobial activity, immunomodulation, antiinflammation, anti-oxidation, and anti-aging effects. These properties render its use for pulpotomy. Studies regarding it are few in the literature which are mentioned below:

- Histopathology events: Aida Meto and Argon Meto, 2017 carried out the study to evaluate the antiinflammatory and regenerative actions of Royal Jelly pastes through histological slides in vital amputation. Paste with "Royal Jelly" positively influenced over radicular pulpal tissue, accelerated the healing and stimulated the odontoblasts. "Royal Jelly" composed in the pastes combined with Propolis to havean expressed action of analgesic, anti-inflammatory, odontoblasts stimulant, regeneration. (44)

\section{Royal Jelly as mouth wash}

Aida $\mathrm{M}$ et al, 2017 carried out the comparative evaluation of effectiveness of Royal Jelly and chlorhexidine as antimicrobial agent against faecalis, $\mathrm{S}$ aureus, S. mutans, E. coli, and C. albican. The study results concluded that Royal Jelly has comparable antimicrobial efficacy with that of $0.2 \%$ chlorhexidine. However, as per Khosla $\mathrm{A}$ et al to get similar results as that of chlorhexidine higher concentrations of Royal Jelly extract with lesser dilutions can be used. (45)

\section{Future scope of Royal Jelly in Dentistry}

Keeping in mind various study results of Royal Jelly

1. It has potential role in wound healing, further vivo studies can be carried out.

2. It can be used as natural remedy for treating periodontal diseases.

3. Royal Jelly can be a good alternative option for storage of avulsed tooth.

4. In cancer patients, oral mucositis can be treated effectively at early stages when Royal Jelly is used as mouth wash. 
5. Royal Jelly can be used for prevention of Denture stomatitis.

6. Its use as pulpotomy medicament can be explored by conducting in vivo studies.

\section{Conclusion}

Royal Jelly can be developed into a potent apitherapeutic agent due to its various pharmacological properties which may avoid usual drawbacks of synthetic medicaments. However, in order to show the efficacy of "Royal Jelly" in human models and to identify successful "Royal Jelly" compounds that may contribute to the synthesis of new drugs, further clinical trials are required.

\section{References}

1. Moritz R, Southwick EE, Bees as superorganisms: an evolutionary reality. Springer Science \& Business Media; Dec 2012.

2. Pavel C. I, Mărghitaş L. A, Bobiş O, Dezmirean D. S, Şapcaliu A, Radoi I, Mădaş M. N Biological Activities Of Royal Jelly-Review.Scientific Papers Animal Science and Biotechnologies. Oct 2011;44(2);108-18.

3. Isidorov V. A, Bakier S, GrzechI, Gas Chromatographic - Mass Spectrometric Investigation Of Volatile And Extractable Compounds Of Crude Royal Jelly. Journal of Chromatography B.Feb2012;885;109-16.

4. Izuta $\mathrm{H}$, Chikaraishi $\mathrm{Y}$, Shimazawa M, Mishima S, Hara H. 10-Hydroxy-2-Decenoic Acid, A Major Fatty Acid From Royal Jelly, Inhibits VEGFInduced Angiogenesis In Human Umbilical Vein Endothelial Cells. Evidence-Based Complementary And Alternative Medicine. Dec2009;6(4);489-94.

5. Khazaei M, Ansarian A, Ghanbari E, New Findings On Biological Actions And ClinicalApplications Of Royal Jelly: A Review. Journal Of Dietary Supplements. Sep $2018 ; 15(5): 757-75$.

6. Melliou E, Chinou I, Chemistry and bioactivities of royal jelly. In Studies in Natural Products Chemistry, Elsevier.Jan2014;(43): 261-90.

7. Ramadan M. F, Al-Ghamdi A, Bioactive Compounds And Health-Promoting Properties OfRoyal Jelly: A Review. Journal Of Functional Foods.Jan 2012;4(1);39-52.

8. Li J, Wang T, Zhang Z, Pan Y, Proteomic Analysis Of Royal Jelly From Three Strains Ofwestern Honeybees (Apis Mellifera). Journal Of Agricultural And Food Chemistry. Oct2007;55(21);8411-22.

9. Genç M, Aslan A, Determination of trans-10hydroxy-2-decenoic acid content in pure royaljelly and royal jelly products by column liquid chromatography. Journal ofChromatography A.Apr1999;839(1-2);265-8.

10. Kitahara T, Sato N, Ohya Y, Shinta H, Hori K, The Inhibitory Effect Of $\Omega$-HydroxyacidsIn Royal Jelly Extract On Sebaceous Gland Lipogenesis. Journal OfDermatologicalScience. Jul 1995;10(1);75.
11. Fontana R, Mendes M. A, De Souza B. M, Konno K, César L. M, Malaspina O, Palma M. S.Jelleines: AFamily Of Antimicrobial Peptides From The Royal Jelly Of Honeybees (Apis mellifera). Peptides.Jun2004;25(6);919-28.

12. Fratini F, Cilia G, Mancini S, Felicioli A, Royal Jelly: An Ancient RemedyWith Remarkable Antibacterial Properties. Microbiological Research.Nov 2016; 192;130-41.

13. Wei W, Wei M, Kang X, Deng H, Lu Z, A Novel Method Developed For AcetylcholineDetection In Royal Jelly By Using Capillary Electrophoresis Coupled With ElectrogeneratedChemiluminescence Based On A Simple Reaction. Electrophoresis. 2009 Jun;30(11);1949-52.

14. Xue XF, Zhou JH, Wu LM, Fu LH, Zhao J, HPLC determination of adenosine in royaljelly. Food Chemistry. Jul2009;115(2):715-9.

15. Coutinho D, Karibasappa SN, Mehta D. S, Royal jelly antimicrobial activity againstperiodontopathic bacteria. Journal of Interdisciplinary Dentistry,Jan 2018;8(1);18.

16. Bílikova K, Huang S. C, Lin I. P, Šimuth J, Peng C.C, Structure And Antimicrobial Activityrelationship Of Royalisin, An Antimicrobial Peptide From Royal Jelly Of Apis Mellifera.Peptides. Jun2015;68;190-6.

17. Furusawa T, Rakwal R, Nam H. W, Shibato J, Agrawal G. K, Kim YS, Ogawa Y, YoshidaY, Kouzuma Y, Masuo Y, Yonekura M, Comprehensive Royal Jelly (RJ) Proteomics Usingone-And TwoDimensional Proteomics Platforms Reveals Novel RJ Proteins AndPotentialphospho/Glycoproteins. Journal Of Proteome Research. Aug 2008;7(8);3194-229.

18. Buttstedt A, Moritz R. F, Erler S, Origin And Function Of The Major Royal Jelly Proteins Of Thehoneybee (Apis Mellifera) As Members Of The Yellow Gene Family. Biological Reviews. May2014;89(2);255-69.

19. Kim B.Y, Lee K. S, Jung B, Choi Y. S, Kim H. K, Yoon H. J, Gui $\mathrm{Z}$ et al., Honeybee(Apis cerana) major royal jelly protein 4 exhibits antimicrobial activity. Journal of Asia-Pacific Entomology.Mar 2019;22(1);175-82.

20. Park M.J, Kim B.Y, Park HG, Deng Y, Yoon H. J, Choi Y. S, Lee K.S, Jin BR Major royal jelly protein 2 acts as an antimicrobial agent and antioxidant in royal jelly. Journal of Asia-Pacific Entomology.2019 Sep 1;22(3):684-9.

21. Fratini F, Cilia G, Mancini S, Felicioli A. Royal Jelly: An ancient remedy with remarkable antibacterial properties. Microbiological Research. 2016 Nov 1;192:130-41.

22. Han B, Fang Y, Feng M, Lu X, Huo X, Meng L, Wu B, Li J, In-Depth PhosphoproteomicAnalysis Of Royal Jelly Derived From Western And Eastern Honeybee Species. Journal Of Proteome Research. Dec2014 ;13(12); 5928-43.

23. Splith K, Neundorf I, Antimicrobial Peptides With Cell-Penetrating Peptide Properties Andvice Versa. 
European Biophysics Journal. Apr2011;40(4);387-97.

24. Fuji A, Kobayashi S, Kuboyama N, Furukawa Y, Kaneko Y, Ishihama S, Augmantation Of Wound Healing By Royal Jelly In Streptozocin Diabetic Rats. J Pharmacol. 1990;53(3);331-7.

25. Kohno K, Okamoto I, Sano O, Arai N, Iwaki K, Ikeda M, Kurimoto, Royal Jelly Inhibitsthe Production Of Proinflammatory Cytokines By Activated Macrophages. Bioscience,Biotechnology, And Biochemistry. Jan2004;68(1);138-45.

26. Koya-Miyata S, Okamoto I, Ushio S, Iwaki K, Ikeda M, Kurimoto, Identification Of Acollagen Production-Promoting Factor From An Extract Of Royal Jelly And Its Possible mechanism. Bioscience, Biotechnology, And Biochemistry. 2004;68(4):767-73.

27. Lin Y, Shao Q, Zhang M, Lu C, Fleming J, Su S, Royal Jelly-Derived Proteins EnhanceProliferation And Migration Of Human Epidermal Keratinocytes In An In Vitro Scratch WoundModel. BMC Complementary And Alternative Medicine. Dec2019;19(1);175.

28. Bucekova M, Sojka M, Valachova I, Martinotti S, Ranzato E, Szep Z, Majtan V, KlaudinyJ, Majtan J, Bee-Derived Antibacterial Peptide, Defensin-1, Promotes Wound ReepithelialisationinVitro And In Vivo. Scientific Reports.Aug2017;7(1);1-3.

29. Ghanbari E, Nejati V, Azadbakht M, Protective Effect Of Royal Jelly Against Renal Damagein Streptozotocin Induced Diabetic Rats.Iranian Journal of Toxicology. 2015; 1258-263

30. Dzink J. L, Socransky S. S, Haffajee A. D, The Predominant Cultivable Microbiota Of Activeand Inactive Lesions Of Destructive Periodontal Diseases. J Clin Periodontol.1988;15:316-23.

31. Slots J, Bragd L, Wikström M, Dahlén G, The oc currence of Actinobacillus actinomycetemcomitans, Bacteroides gingivalis and Bacteroides intermedius in destructive periodontal disease in adults. Journal of clinical periodontology. $1986 \mathrm{Jul} ; 13(6): 570-7$.

32. Yanagita M, Kojima Y, Mori K, Yamada S, Murakami S, Osteoinductive and anti-inflammatory effect of royal jelly on periodontal ligament cells. Biomedical Research.2011;32(4):285-91.

33. Kaku M, Rocabado JM, Kitami M, Ida T, Uoshima $\mathrm{K}$, Royal jelly affects collagen cross linking in bone of ovariectomized rats. Journal of Functional Foods. 2014 Mar1;7:398-406.

34. Kim J, Kim Y, Yun H, Park H, Kim SY, Lee KG, et al. Royal jelly enhances migration ofhuman dermal fibroblasts and alters the levels of cholesterol and sphinganine in an in vitrowound healing model.
Nutrition research and practice. 2010 Oct 1;4(5):362-8.

35. Koya-Miyata S, Okamoto I, Ushio S, Iwaki K, Ikeda $M$ and Kurimoto $M$. Identification ofa collagen production-promoting factor from an extract of royal jelly and its possiblemechanism. Biosci Biotechnol Biochem 2004; 68: 767-73.

36. Dhanesuan N, Srisuparbh D, Tiranathanagul S, Rungsiyanont $S$, The In Vitro Effect ofRoyal Jelly, Apis mellifera, on Proliferation of Human Gingival, Periodontal LigamentFibroblasts and Human Bone Cells. Thai Pharmaceutical and Health Science Journal-วารสารไทยเภสัชศาสตร์และวิทยาการ สุขภาพ. 2011 Jan 7;6(3):182-7.

37. Sricholpech M, Srisupabh D, Royal jelly promotes the viability and proliferation ofperiodontal ligament fibroblasts in an in vitro tooth avulsion simulation. M Dent J.2015;35:47-56.

38. Erdem Ö, Güngörmüs Z. The effect of royal jelly on oral mucositis in patients undergoing radiotherapy and chemotherapy. Holistic Nursing Practice. Jul 2014 1;28(4):242-6.

39. Watanabe S, Suemaru K, Takechi K, Kaji H, Imai $\mathrm{K}$, Araki $\mathrm{H}$. Oral mucosal adhesive filmscontaining royal jelly accelerate recovery from 5-fluorouracilinduced oral mucositis.Journal of Pharmacological Sciences. 2013:12181FP.

40. Abdelatif M, Yakoot M, Etmaan M. Safety and efficacy of a new honey ointment ondiabetic foot ulcers: a prospective pilot study. Journal of wound care. 2008 Mar; 17(3):108-10.

41. He XY, Meurman JH, Kari K, Rautemaa R, Samaranayake LP. In vitro adhesion of Candida species to denture base materials. Mycoses. 2006 Mar;49(2):80-4.

42. Bilikova K, Krakova TK, Yamaguchi K, Yamaguchi Y. Major royal jelly proteins as markers of authenticity and quality of honey. Archives of Industrial Hygiene and Toxicology. Dec 2015; 66(4);259-67.

43. Jareemit D, Srisuparbh D, Didron PP. Efficacy of Royal Jelly Extract on Inhibition of Candida Albicans Adherence on Various Types of Denture Base Material. JDAT DFCT 2017 (Suppl Issue VOL.67)

44. Meto A, Meto A, Pastes based on Royal Jelly, an alternative for the minimally invasive treatment of pulpitis (histopathological experimental data). Albanian Journal of Biomedica Sciences. 2017:1.

45. Meto A, Meto A, Xhajanka E, Özcan M, Tragaj E, Microbiological comparison of royal jelly and chlorhexidine $0.2 \%$, European Journal of Interdisciplinary Studies. 2017 Feb1;3(2):123-6. 